\title{
Development of Breast Cancer Spheroids to Evaluate Cytotoxic Response to an Anticancer Peptide
}

\author{
Marco Cavaco ${ }^{1,2,+}$, Patrícia Fraga ${ }^{1,+}$, Javier Valle ${ }^{2} \mathbb{D}$, David Andreu ${ }^{2} \mathbb{D}$, Miguel A. R. B. Castanho ${ }^{1} \mathbb{D}$ \\ and Vera Neves $1, *$ (D)
}

check for updates

Citation: Cavaco, M.; Fraga, P.; Valle, J.; Andreu, D.; Castanho, M.A.R.B.; Neves, V. Development of Breast Cancer Spheroids to Evaluate Cytotoxic Response to an Anticancer Peptide. Pharmaceutics 2021, 13, 1863. https://doi.org/10.3390/ pharmaceutics13111863

Academic Editors: João Sousa, Carla Vitorino and Alberto A. C. C. Pais

Received: 6 October 2021

Accepted: 2 November 2021

Published: 4 November 2021

Publisher's Note: MDPI stays neutral with regard to jurisdictional claims in published maps and institutional affiliations.

Copyright: (c) 2021 by the authors. Licensee MDPI, Basel, Switzerland. This article is an open access article distributed under the terms and conditions of the Creative Commons Attribution (CC BY) license (https:// creativecommons.org/licenses/by/ $4.0 /)$.
1 Department of Biochemistry, Instituto de Medicina Molecular João Lobo Antunes, Faculdade de Medicina, Universidade de Lisboa, Av. Prof. Egas Moniz, 1649-028 Lisbon, Portugal; mcavaco@medicina.ulisboa.pt (M.C.); pfraga@medicina.ulisboa.pt (P.F.); macastanho@medicina.ulisboa.pt (M.A.R.B.C.)

2 Proteomics and Protein Chemistry Unit, Department of Experimental and Health Sciences, Pompeu Fabra University, Dr. Aiguader 88, Barcelona Biomedical Research Park, 08003 Barcelona, Spain; javier.valle@upf.edu (J.V.); david.andreu@upf.edu (D.A.)

* Correspondence: veraneves@medicina.ulisboa.pt; Tel.: +351-21-799-94-11 (ext. 47256)

$+\quad$ These authors contributed equally.

\begin{abstract}
Breast cancer (BC) is the most commonly diagnosed cancer in women and one of the most common causes of cancer-related deaths. Despite intense research efforts, BC treatment still remains challenging. Improved drug development strategies are needed for impactful benefit to patients. Current preclinical studies rely mostly on cell-based screenings, using two-dimensional (2D) cell monolayers that do not mimic in vivo tumors properly. Herein, we explored the development and characterization of three-dimensional (3D) models, named spheroids, of the most aggressive BC subtypes (triple-negative breast cancer-TNBC; and human-epidermal growth receptor-2-HER2+), using the liquid overlay technique with several selected cell lines. In these cell line-derived spheroids, we studied cell density, proliferation, ultrastructure, apoptosis, reactive oxygen species (ROS) production, and cell permeabilization (live/dead). The results showed a formation of compact and homogeneous spheroids on day 7 after seeding 2000 cells/well for MDA-MB-231 and 5000 cells/well for BT-20 and BT-474. Next, we compared the efficacy of a model anticancer peptide (ACP) in cell monolayers and spheroids. Overall, the results demonstrated spheroids to be less sensitive to treatment than cell monolayers, revealing the need for more robust models in drug development.
\end{abstract}

Keywords: 3D cell culture; anticancer peptides; breast cancer; cell monolayers; preclinical studies; spheroids

\section{Introduction}

Over the last decade, breast cancer $(\mathrm{BC})$ diagnosis and treatment have significantly improved, resulting in better disease management. Nevertheless, BC is still one of the leading causes of cancer-related deaths among women worldwide [1].

The classification of BCs into different subtypes is important to select adequate therapeutic options and evaluate prognosis, with the histological profile as one of the most important criteria. BCs can be classified into invasive ductal carcinoma (80-85\% of patients), invasive lobular carcinoma (10-15\%), and ductal/lobular carcinoma (5-10\%) [2,3]. The occurrence of two molecular targets, namely estrogen-receptor $\alpha(E R \alpha)$ and epidermal growth factor receptor-2 (HER2), constitutes another classification criterion [4]. Er $\alpha$ is expressed in $75 \%$ of invasive BCs, and it is closely related to the expression of the progesteronereceptor (PR) [5,6]. HER2 is amplified or overexpressed in 15-20\% of BCs [7,8]. Finally, triple-negative breast cancer (TNBC), which corresponds to approximately $10-15 \%$ of BCs, is characterized by the lack of ER/PR and HER2 expression [9,10]. 
In the last decade, significant advances have been made in the understanding of cancer onset and survival, and in the development of new therapeutic platforms allowing the development of new therapeutics against these more aggressive BC subtypes, namely HER2+ and TNBC [4,6]. However, only a small percentage of drugs have advanced into the clinic and are currently in use [11]. In the early stages, both BC subtypes are manageable; however, in advanced stages, therapy is based on palliative care, which underscores the lack of effective drugs [12].

The development of new drugs is a demanding and time-consuming process [13]. Usually, it encompasses several in vitro and in vivo screens before assessment in humans. To date, the evaluation of a new drug in an in vitro setting relies primarily on cell-based assays, which provide an easy-to-use, fast, and cost-effective tool [14]. Most of these assays use traditional two-dimensional (2D) cell monolayers, cultured on flat and rigid substrates [14]. Although useful, these cultures do not adequately reproduce the natural three-dimensional (3D) cell microenvironment [15-17]. In cancer research, the tumor microenvironment is particularly important, given unique features such as the existence of hypoxic areas, production of extracellular matrix, intercellular interactions, and growth factor exchange [18]. Consequently, the lack of similarities between 2D cell culture models and the in vivo setting might be one of the main reasons for the high percentage of drugs failing clinical trials, albeit promising in early development stages [19-21].

In contrast to 2D cell models, it has been suggested that 3D models are more representative of the actual in vivo tumor microenvironment [22-27], which makes them promising tools for drug development. Numerous 3D culture methods have been studied to generate these models based on (1) the application of automated forces (e.g., centrifugation, spinning, and rotation), (2) hydrogels, and (3) gravity (e.g., hanging drop culture, and liquid overlay culture) [28-30]. Based on these different techniques, researchers have been developing spheroids using different cancer cell types and matrices to accurately study chemotherapeutic drugs [28,31-41].

This work focuses on the development of BC spheroids for TNBC (MDA-MB-231 and BT-20, which lack common target receptors and differ in proliferation and metastization capability) and HER2+ (BT-474, which expresses growth receptors and presents a high proliferative rate, as well as a relatively high rate of cell loss) cell subtypes highly applied in preclinical studies with chemotherapeutic agents [42]. The liquid overlay culture technique, which allows the formation of pseudo-microtissues, also called spheroids, is based mostly on cell seeding (gravity) in an untreated round-bottomed well, and was chosen as a simple and fast procedure capable of generating highly homogeneous and reproducible spheroids. During protocol optimization, each cell line-derived spheroid was thoroughly characterized by evaluation of cell density, metabolic activity, cell permeabilization (live/dead), apoptosis, oxidative stress, proliferation, and ultrastructure, providing a privileged vantage point over other spheroid production protocols. Such well-characterized BC spheroids provide a realistic setting of the tumor biochemical and biophysical microenvironment vis-à-vis drug testing.

After selecting optimal conditions to develop stable and homogenous spheroids, we compared the efficacy of an anticancer peptide (ACP), vCPP2319 [43,44], in cell monolayers and spheroids. Therapeutic peptides such as vCPP2319 have been explored as a potential alternative to classical chemotherapeutic agents for advantages, such as efficiency, specificity and affinity, minimal drug-drug interactions, and biological and chemical diversity [45-47], and like chemotherapeutic agents, lack proper characterization in more robust models, such as spheroids. In this study, vCPP2319 efficacy was compared with PepH3, known for penetration of cellular barriers but lacking anticancer activity [43]. The proposed comparison will demonstrate the importance of using complex cell culture models for an accurate evaluation of drug efficacy. 


\section{Materials and Methods}

\subsection{Chemicals and Materials}

3,6-dioxa-1,8-octanedithiol (DODT) was purchased from Sigma-Aldrich (Spain). Solvents and reagents for peptide synthesis ( $N, N$-dimethylformamide (DMF), $N, N$ diisopropylethylamine (DIEA), dichloromethane (DCM), trifluoroacetic acid (TFA), N,Ndiisopropylcarbodiimide (DIPCI), and triisopropylsilane (TIS)), as well as HPLC-grade acetonitrile (CAN) were purchased from Carlo Erba-SDS (Sabadell, Spain). Fmoc-protected amino acids, Fmoc-Rink amide (MBHA) resin, $\mathrm{N}$-hydroxybenzotriazole $(\mathrm{HOBt})$, and 2-(1H-benzotriazol-1-yl)-1,1,3,3-tetramethyluronium hexafluorophosphate (HBTU) were purchased from Iris Biotech (Marktredwitz, Germany).

Dulbecco's modified Eagle medium (DMEM), trypsin-EDTA, fetal bovine serum (FBS), L-glutamine, and penicillin-streptomycin antibiotic solution (pen/strep solution) were purchased from Gibco/Thermo Fischer (Waltham, MA, USA). Eagle's minimum essential medium (EMEM) was purchased from Sigma-Aldrich (Madrid, Spain). CellTiter-Blue ${ }^{\circledR}$ cell viability reagent was purchased from Promega (Madrid, Spain). CellEvent ${ }^{\mathrm{TM}}$ ReadyProbe $^{\circledR}$, CellRox ${ }^{\circledR}$ Deep Red reagent, and Live/Dead ${ }^{\mathrm{TM}}$ viability/cytotoxicity kit were purchased from Invitrogen/Thermo Fisher (Waltham, MA, USA).

\subsection{Cell Culture}

TNBC cell lines MDA-MB-231 (ATCC ${ }^{\odot}$ HTB-26 $^{\text {TM}}$ ) and BT-20 (ATCC ${ }^{\odot}$ HTB-19 $^{\mathrm{TM}}$ ) were cultured as a monolayer in DMEM and EMEM, respectively. The HER2+ cell line BT-474 (ATCC ${ }^{\odot}$ HTB-20 ${ }^{\mathrm{TM}}$ ) was cultured as a monolayer in EMEM. Additionally, we added $10 \%$ FBS and $1 \%$ pen/strep solution to the respective medium, following the instructions from the manufacturer. All cells grew in a humidified atmosphere at $37^{\circ} \mathrm{C}$ and $5 \% \mathrm{CO}_{2}$ (MCO-18AIC (UV), Sanyo, Osaka, Japan). The medium was changed every other day.

\subsection{Tumor Spheroid Generation}

Cells were allowed to grow until $80 \%$ confluence in a $75 \mathrm{~cm}^{2}$ T-flask. Then, spheroids were generated using the liquid overlay technique. Briefly, cells were seeded in an ultra-low attachment 96-well round-bottomed plate with covalently bonded hydrogel that minimizes cell attachment (Ref. 7007, Corning, NY, USA). For spheroid optimization, a seeding density of 50 to 10,000 cells/well was used, after which the optimal regimen conditions were established for each spheroid and used for all remaining assays: 2000 cells/well for MDAMB-231 and 5000 cells/well for BT-20 and BT-474. A cold $\left(4^{\circ} \mathrm{C}\right)$ solution of GelTrex ${ }^{\circledR}$ LDEVfree (Alfagene/Thermo Fisher, Waltham, MA, USA) diluted in the respective medium was added into each well $(2 \%, v / v)$ after $24 \mathrm{~h}$. Then, microplates were agitated (185 rpm for $20 \mathrm{~min}$ ) and put in the incubator under culturing conditions until the day of the experiment. During the optimization assay, spheroids were cultured for 14 days without changing or adding medium. After determination of the best regimen conditions, a 7-day incubation period was considered optimal and used in subsequent studies.

\subsection{Characterization of Spheroid Diameter and Morphology}

During spheroid optimization, diameter and morphology were monitored daily from day 1 (i.e., the day after addition of cellular matrix) to day 14, using the wide field fluorescence microscope Zeiss Axiovert 200M (Carl Zeiss, Oberkochen, Germany) equipped with an EC Plan-Neofluar $\times 10$ dry objective ( 0.30 numerical aperture) and a Leica DFC450 camera. The diameter of each spheroid was measured with the "cellular analysis" algorithm using Fiji software. At least three replicates on different days were used.

\subsection{Metabolic Activity Assessment}

The metabolic activity of spheroids was monitored daily from day 1 to 14 during the optimization procedure, using CellTiter-Blue ${ }^{\circledR}$ cell viability assay, according to the manufacturer's instructions. Briefly, on the day of the experiment, $20 \mu \mathrm{L}$ of CellTiterBlue $^{\circledR}$ reagent was added to each well and incubated for $6 \mathrm{~h}$ in culturing conditions. The 
fluorescence intensity was measured at $560 \mathrm{~nm}$ excitation and $590 \mathrm{~nm}$ emission using the Varioskan $^{\mathrm{TM}}$ LUX microplate reader (Thermo Fisher, Waltham, MA, USA). At least three replicates on different days were used.

\subsection{Apoptosis Determination}

Activation of apoptosis was measured with a CellEvent ${ }^{\mathrm{TM}}$ ReadyProbe $^{\mathrm{TM}}$, according to the manufacturer's instructions. Briefly, on the day of the experiment, spheroids were harvested and transferred into 6-well flat-bottomed plates (Corning, NY, USA), washed twice with $1 \times$ PBS (pH 7.4), and incubated with the probe for $60 \mathrm{~min}$. Then, we transferred the spheroids to 8-well $\mu$-slides (Ibidi, Gräfelfing, Germany) and used a confocal pointscanning Zeiss LSM 880 microscope (Carl Zeiss, Oberkochen, Germany) equipped with an alpha Plan-Apochromat $\times 20$ dry objective ( 0.80 numerical aperture) to image them. We selected a 488-nm Ar laser to excite the probe. The images were recorded in the normal confocal mode at $3440 \times 3440$ resolution using $\times 0.6$ zoom. To acquire and process all images, we used Zen and Fiji software. At least three replicates on different days were used.

\subsection{Oxidative Stress Measurement}

The production of reactive oxygen species (ROS) was measured using a CellRox ${ }^{\circledR}$ Deep Red reagent, according to the manufacturer's instructions. Briefly, on the day of the experiment, spheroids were harvested and transferred into 6-well flat-bottomed plates (Corning, NY, USA), washed twice with $1 \times$ PBS (pH 7.4), and incubated with CellRox ${ }^{\circledR}$ reagent $(5.0 \mu \mathrm{M})$ for $60 \mathrm{~min}$. Then, we transferred the spheroids to 8-well $\mu$-slides (Ibidi, Gräfelfing, Germany) and used a confocal point-scanning Zeiss LSM 880 microscope (Carl Zeiss, Oberkochen, Germany) equipped with an alpha Plan-Apochromat $\times 20$ dry objective (0.80 numerical aperture) to image them. We selected a 633-nm HeNe633 laser to excite the probe. The images were recorded in the normal confocal mode at $3440 \times 3440$ resolution using $\times 0.6$ zoom. To acquire and process all images, we used Zen and Fiji software. At least three replicates on different days were used.

\subsection{Spheroid Viability Monitoring}

Spheroid viability was monitored using a Live/Dead ${ }^{\mathrm{TM}}$ viability/cytotoxicity kit, according to the manufacturer's instructions. Briefly, on the day of the experiment, spheroids were harvested and transferred into 6-well flat-bottomed plates (Corning, NY, USA), washed twice with $1 \times$ PBS ( $\mathrm{pH} 7.4$ ), and incubated with ethidium homodimer-1 (EthD-1, $4.0 \mu \mathrm{M}$ in $1 \times$ PBS (pH 7.4)) and calcein-AM (2.0 $\mu \mathrm{M}$ in $1 \times \mathrm{PBS}(\mathrm{pH} 7.4))$ for $45 \mathrm{~min}$. Then, we transferred the spheroids to 8-well $\mu$-slides (Ibidi, Gräfelfing, Germany) and used a confocal point-scanning Zeiss LSM 880 microscope (Carl Zeiss, Oberkochen, Germany) equipped with an alpha Plan-Apochromat $\times 20$ dry objective ( 0.80 numerical aperture) to image them. We selected a 488- and 514-nm Ar laser to excite the probes. The images were recorded in the normal confocal mode at $3440 \times 3440$ resolution using $\times 0.6 \mathrm{zoom}$. To acquire and process all images, we used Zen and Fiji software. At least three replicates on different days were used.

\subsection{Transmission Electron Microscopy}

Cell organization and ultrastructure within spheroids were observed by transmission electron microscopy (TEM). Established spheroids were washed in $0.1 \mathrm{M}$ Na cacodylate buffer ( $\mathrm{pH} 7.4$ ) and fixed in $2.5 \%$ glutaraldehyde for $24 \mathrm{~h}$ at $4{ }^{\circ} \mathrm{C}$. Specimens were then washed $3 \times(10 \mathrm{~min})$, post fixed for $1 \mathrm{~h}$ with $1 \%$ osmium tetroxide, and washed $3 \times$, all steps in Na cacodylate buffer. Then, spheroids were dehydrated in ethanol (70\%, 95\%, $100 \%$ ) and propylene oxide and infiltrated with propylene oxide and EPON resin mixture (2:1, 1:1, 1:2 for $1 \mathrm{~h})$. Subsequently, they were embedded in EPON resin overnight at room temperature and incubated for 2 days at $60^{\circ} \mathrm{C}$. Next, we cut the specimens using a UC7 ultramicrotome (Leica) into thin sections $(70 \mathrm{~nm}$ ) and stained with uranyl acetate and lead 
citrate. The cells' ultrastructural organization within the spheroids was observed using TEM (Hitachi H-7000 microscope) at $100 \mathrm{kV}$ acceleration voltage. Micrographs were made using a MegaView III camera placed in a side position.

\subsection{Peptide Synthesis and Purification}

PepH3 (AGILKRW-amide) and vCPP2319 (WRRRYRRWRRRRRQRRRPRR-amide) were both produced by solid phase peptide synthesis on Rink-amide ChemMatrix resin at $0.1 \mathrm{mmol}$ scale in a Gyros Prelude (Tucson, AZ, USA) instrument running Fmoc protocols (Table 1). Trifunctional residue side chain protections were tert-butyloxycarbonyl (Trp), tertbutyl (Glu, Ser, Thr, and Tyr), and NG-2,2,4,6,7-pentamethyldihydrobenzofuran-5-sulfonyl (Arg). Couplings were achieved with an 8-fold molar excess of both Fmoc amino acid and HBTU, plus a 16-fold molar excess of DIEA, in DMF. After chain assembly, treatment with TFA $/ \mathrm{H}_{2} \mathrm{O} /$ DODT / TIS (94:2.5:2.5:1 $v / v, 90 \mathrm{~min}$, r.t.) achieved full deprotection and resin cleavage. The crude peptide was precipitated from the TFA solution by cold ether addition and centrifugation $\left(4000 \times \mathrm{g}, 4{ }^{\circ} \mathrm{C}\right.$ for $20 \mathrm{~min}$ ), and the pellet was dissolved in $\mathrm{H}_{2} \mathrm{O}$ and lyophilized.

Table 1. Peptides used in this study.

\begin{tabular}{llccc}
\hline \multicolumn{1}{c}{ Peptide } & \multicolumn{1}{c}{ Amino Acid Sequence } & $\begin{array}{c}\text { Mass (Da), } \\
\text { Calculated (Found) }\end{array}$ & $\begin{array}{c}\text { HPLC } \mathbf{t}_{\mathbf{R}} \\
\text { (min) }\end{array}$ & $\begin{array}{c}\text { Purity } \\
\text { (\%) }\end{array}$ \\
\hline PepH3 & AGILKRW-amide & $842.8(843.0)$ & 5.5 & 99.5 \\
vCPP2319 & WRRRYRRWRRRRRWRRRPRR-amide & $3179.8(3180.2)$ & 6.9 & 99.1 \\
\hline
\end{tabular}

${ }^{1}$ Peptide purity was estimated by peak integration of the analytical HPLC chromatograms. Da, dalton; $\mathrm{t}_{\mathrm{R}}$, retention time.

Analysis of peptide purity was performed by RP-HPLC (Luna C18 column, $4.6 \times 50 \mathrm{~mm}$, $3.0 \mu \mathrm{m}$; Phenomenex, Torrance, CA, USA) using a linear gradient of solvent $\mathrm{B}(0.036 \%$ TFA in $\mathrm{MeCN})$ into $\mathrm{A}\left(0.045 \%\right.$ TFA in $\left.\mathrm{H}_{2} \mathrm{O}\right)$ at $1 \mathrm{~mL} / \mathrm{min}$ flow rate and with $220 \mathrm{~nm}$ UV detection. Preparative purification was performed by RP-HPLC (Luna C18 column, $21.2 \times 250 \mathrm{~mm}$, $10.0 \mu \mathrm{m}$; Phenomenex) using a linear gradient of solvent B (0.1\% TFA in MeCN) into A $\left(0.1 \%\right.$ TFA in $\left.\mathrm{H}_{2} \mathrm{O}\right)$ at $25 \mathrm{~mL} / \mathrm{min}$ flow rate and with $220 \mathrm{~nm}$ UV detection. Molecular mass determination was performed by LC-MS (XBridge C18 column, $4.6 \times 150 \mathrm{~mm}, 3.5 \mu \mathrm{m}$; Waters, Madrid, Spain) using $\mathrm{HCOOH} / \mathrm{MeCN}(0.08 \% v / v)$ into $\mathrm{HCOOH} / \mathrm{H}_{2} \mathrm{O}(0.1 \%, v / v)$ over $15 \mathrm{~min}$ at $1 \mathrm{~mL} / \mathrm{min}$. HPLC-homogeneous fractions with the expected mass were combined and lyophilized. One millimole peptide stocks in $\mathrm{H}_{2} \mathrm{O}$ were stored at $-20^{\circ} \mathrm{C}$.

\subsection{Cell Viability Measurement on Cell Monolayers}

Peptide cytotoxicity towards MDA-MB-231, BT-20, and BT-474 cell monolayers was determined using a protocol described elsewhere [43]. Different peptide concentrations (0.05-100.0 $\mu \mathrm{M}$ range, in medium), commonly applied in viability screenings, were incubated for $24 \mathrm{~h}$ in culturing conditions. $\mathrm{IC}_{50}$ values were obtained using GraphPad Prism 7.0 software (GraphPad Software, San Diego, CA, USA) and the log(inhibitor) vs. normalized response. At least three replicates on different days were performed.

\subsection{Cell Viability Measurements on Spheroids}

For MDA-MB-231, and for both BT-20 and BT-474, initial densities of 2000 and 5000 cells/well were used, respectively, with 7-day incubation in all cases. After spheroid formation, cells were treated with increasing peptide concentrations $(0.05-100.0 \mu \mathrm{M}$, in medium) up to 5 days in culturing conditions without medium change, and cell viability was assessed using the CellTiter-Blue ${ }^{\circledR}$ assay, as described above. A 5-day incubation was used to assess the period necessary for best anticancer activity. $\mathrm{IC}_{50}$ values were obtained using GraphPad Prism 7.0 software (GraphPad Software, San Diego, CA, USA) and the $\log$ (inhibitor) vs. normalized response. At least three replicates on different days were performed. 


\subsection{Evaluation of Peptide Activity on Spheroids}

The activity was evaluated using the parameters described above for spheroid optimization: apoptosis induction, oxidative stress, and cell permeabilization (live/dead). Briefly, spheroids were incubated for 5 days in culturing conditions with peptide at the $\mathrm{IC}_{50}$ value corresponding to the cell line, without medium change, and the specific assay was performed afterward. To compare fluorescence intensity among different spheroids, corrected total cell fluorescence (CTCF) was calculated using Equation (1):

$\mathrm{CTCF}=$ Integrated Density $-($ Area of selected spheroid $\times$ Mean Fluorescence of background readings $)$

At least three replicates on different days were used.

\subsection{Statistical Analysis}

Results were expressed as means \pm standard deviation (SD) of $n$ independent experiments. All experiments were performed at least in triplicate on three different days. Then, a one-way ANOVA was applied. Tests were two-sided and the nominal level of significance was $^{*} p<0.05,{ }^{* *} p<0.01,{ }^{* * *} p<0.001$, and ${ }^{* * * *} p<0.0001$.

\section{Results}

\subsection{Optimization of Spheroid Generation}

The optimization of MDA-MB-231, BT-20, and BT-474 spheroids was carried out using an initial cell density of 50 to 10,000 cells / well in the presence of $2 \%(v / v)$ GelTrex ${ }^{\circledR}$ over 14 days. Diameter and metabolic activity were evaluated daily. In addition, at days 7 and 14 , apoptotic cells, ROS production, and cell permeabilization (live/dead) were monitored. All of these parameters were used to set the best regimen condition for each cell line.

\subsubsection{MDA-MB-231 Cell Line}

For MDA-MB-231, a progressive increase in diameter was observed until day 7 for all cell densities tested (Figure 1A). On day 14, a slight decrease for 1000, 2000, 5000, and 10,000 cells/well was observed. In contrast, for 50 and 100 cells/well, the diameters continued to increase until day 14 . The metabolic activity reached a maximum between day 7 and day 9 , followed by a significant decrease until day 14 (Figure 1B). The exceptions were 50 and 100 cells/well, where maximum metabolic activity was registered on day 11 with an abrupt metabolic decrease until day 14 .

The best results were observed for 2000 cells/well, for which a gradual increase in diameter and metabolic activity were obtained until day 7 , followed by a stabilization of diameter and increase in metabolic activity between days 7 and 14. Therefore, days 7 and 14 were selected to evaluate specific parameters, such as cell viability (live/dead), apoptosis, and oxidative stress-ROS (Figure 1C). Results showed that most cells remained intact (live), in spite of demonstrating signals of apoptosis. Additionally, no ROS was detected. Considering all the parameters tested, the established regimen conditions for subsequent studies were an initial density of 2000 cells/well and incubation for 7 days (Video S1). 
A

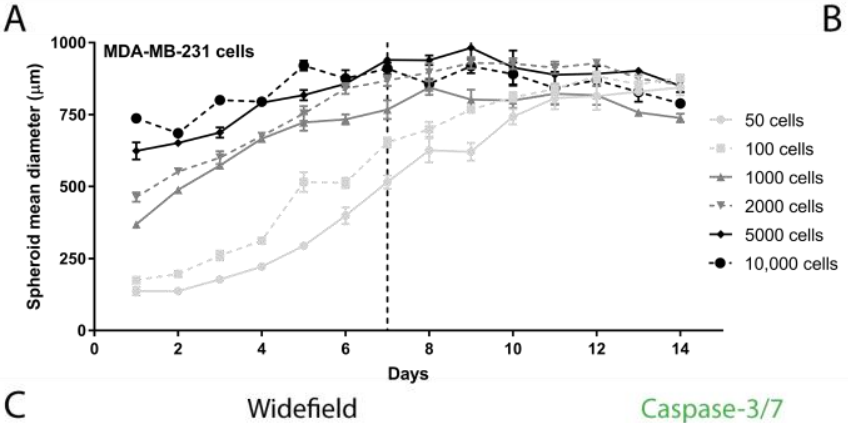

B

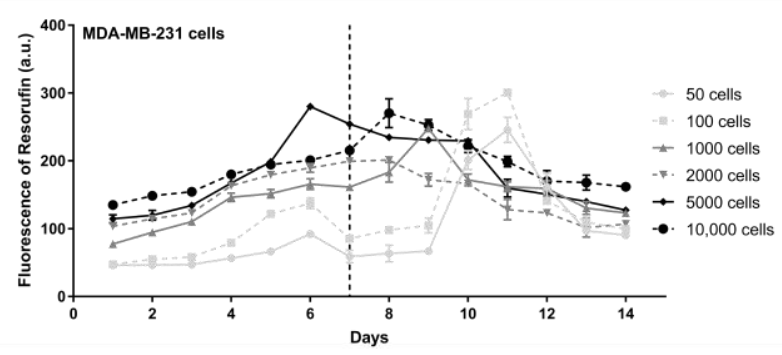

Live/Dead
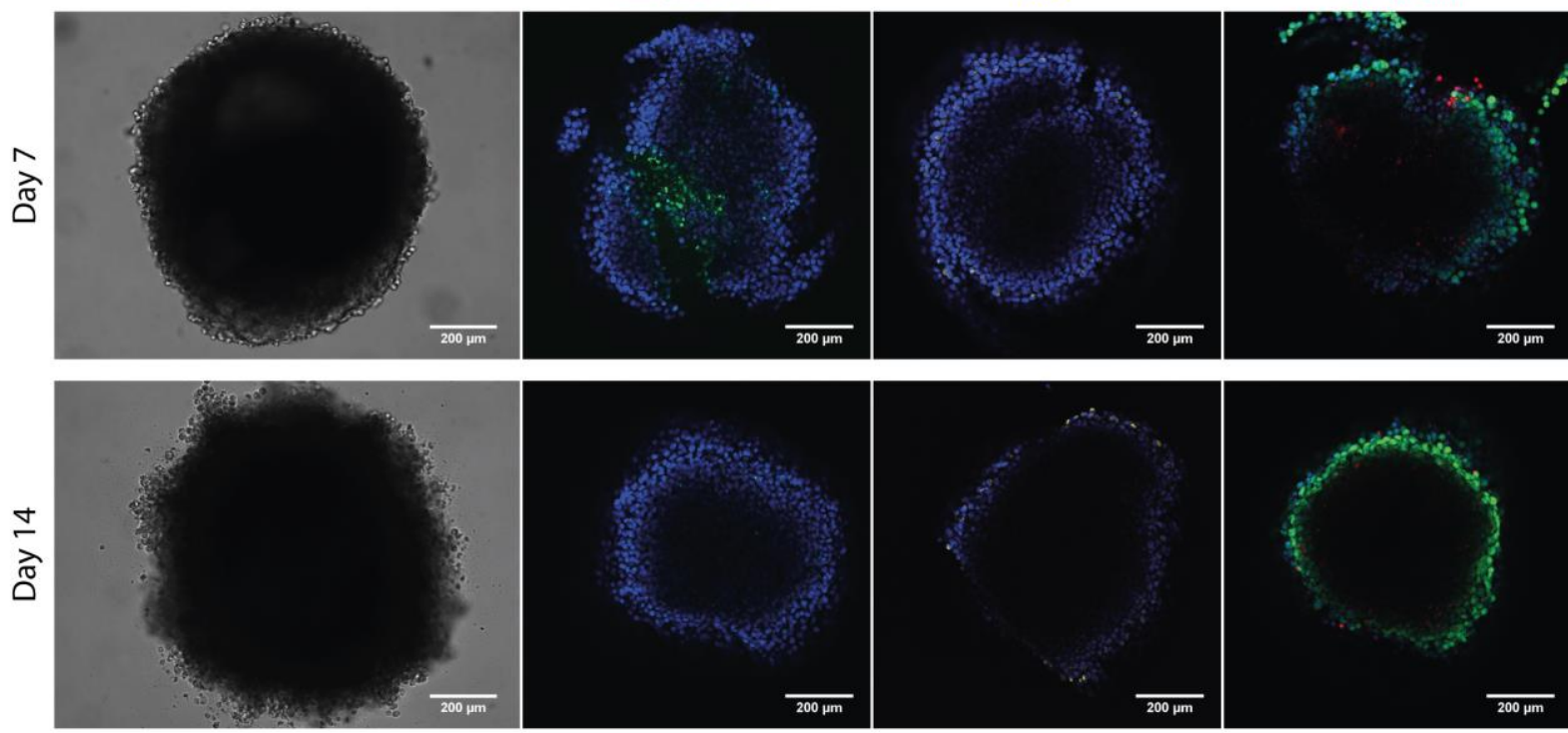

Figure 1. Evaluation of the MDA-MB-231 spheroid formation. (A) Spheroid diameter ( $\mu \mathrm{m})$ daily monitoring over 14 days measured with a widefield fluorescence microscope. (B) Spheroid cell metabolic activity daily evaluation over 14 days by measuring the fluorescence emission of resorufin with a microplate reader. (C) Representative images of parameters evaluated on days 7 and 14 at 2000 cells/well with a confocal point-scanning Zeiss LSM 880 microscope. In the apoptosis determination, apoptotic cells are marked in green; in the oxidative stress measurement, reactive oxygen species (ROS) are marked in yellow; and in the cell viability/mortality evaluation, intact cells (live) are marked in green and permeabilized cells (dead) in red. In all experiments, cell nucleus is marked in blue. Scale bar $=200 \mu \mathrm{m}$. Graphs represent at least three biological repeats.

\subsubsection{BT-20 Cell Line}

For BT-20, the diameter increased over time until day 14 for all initial cell densities with the exception of 10,000 cells/well (Figure 2A). The metabolic activity showed a maximum between days 7 and 8 in the range of 1000 to 10,000 cells/well (Figure 2B). Then, a significant decrease until day 14 was observed. There was a slight increase in the fluorescence intensity up to day 9, followed by a weak decrease for 50 and 100 cells/well.

The best results were observed with 5000 cells/well, where a gradual increase in the diameter and metabolic activity were observed until day 7, followed by diameter stabilization and decrease in metabolic activity between days 7 and 14 . Again, days 7 and 14 were selected to evaluate specific parameters (Figure $2 \mathrm{C}$ ). Results revealed that most cells were intact, with an increase in production of ROS on day 7, while on day 14 an increase in apoptosis was detected. Based on these results, the regimen conditions for subsequent studies were an initial cell density of 5000 cells/well and a growth period of 7 days (Video S2). 
A

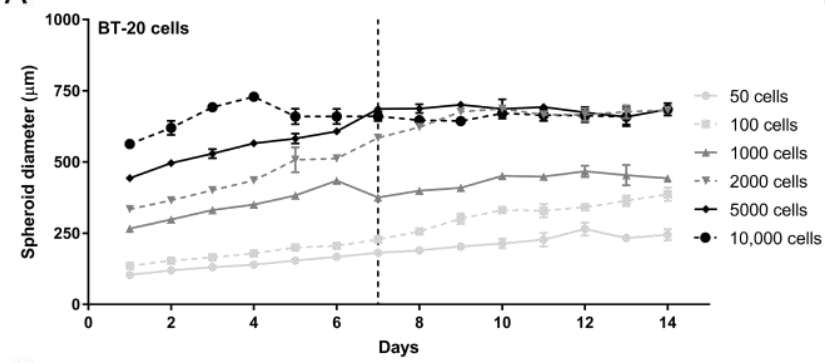

C
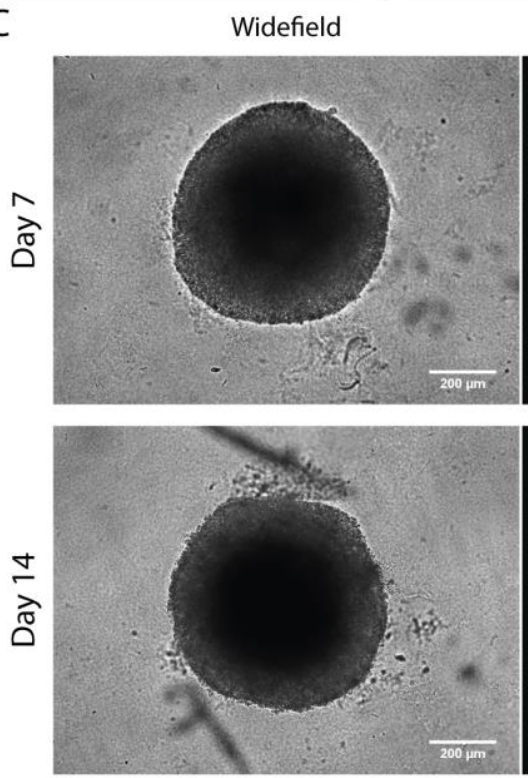

Caspase-3/7
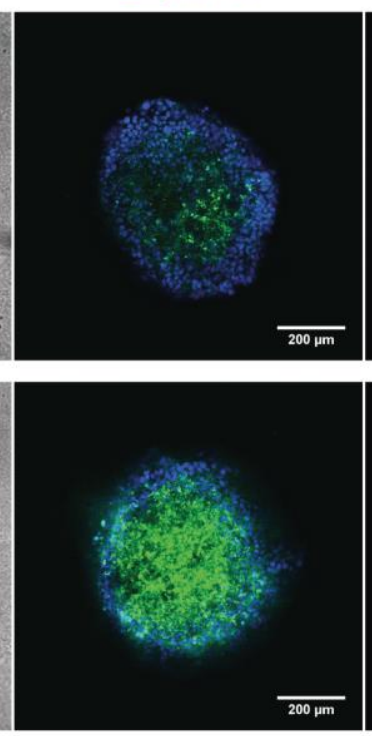

B

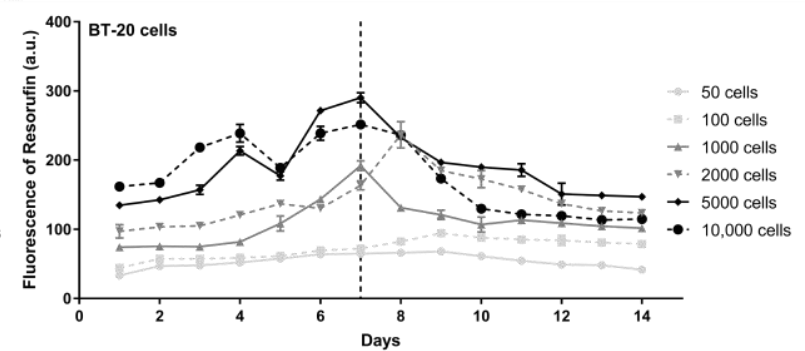

Live/Dead
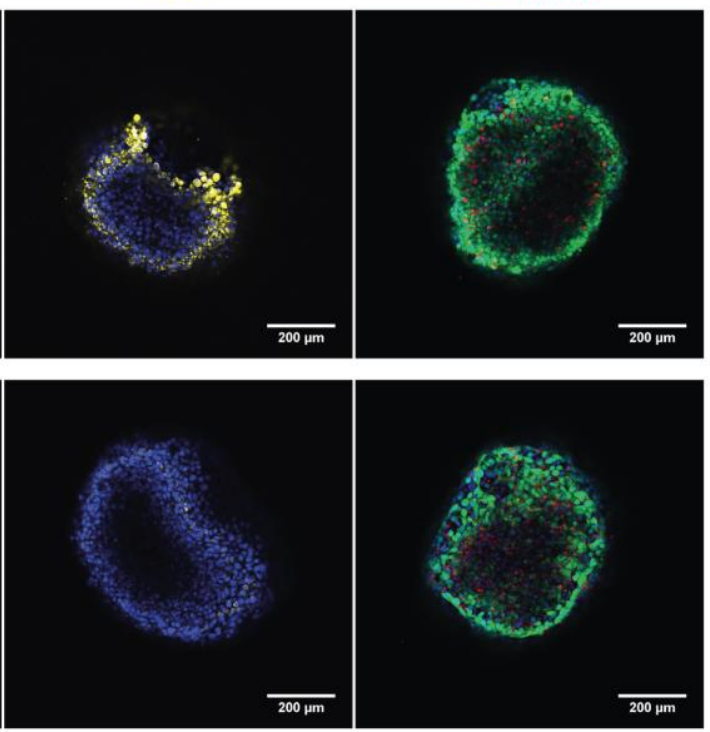

Figure 2. Evaluation of the BT-20 spheroid formation. (A) Spheroid diameter $(\mu \mathrm{m})$ daily monitoring over 14 days measured with a widefield fluorescence microscope. (B) Spheroid cell metabolic activity daily evaluation over 14 days by measuring the fluorescence emission of resorufin with a microplate reader. (C) Representative images of parameters evaluated on days 7 and 14 at 5000 cells/well with a confocal point-scanning Zeiss LSM 880 microscope. In the apoptosis determination, apoptotic cells are marked in green; in the oxidative stress measurement, reactive oxygen species (ROS) are marked in yellow; and in the cell viability/mortality evaluation, intact cells (live) are marked in green and permeabilized cells (dead) in red. In all experiments, cell nucleus is marked in blue. Scale bar $=200 \mu \mathrm{m}$. Graphs represent at least three biological repeats.

\subsubsection{BT-474 Cell Line}

BT-474 spheroid diameters showed a steady increase until day 14, except for 10,000 cells/well, with diameters decreasing after day 7 (Figure 3A). As for metabolic activity, there was a maximum on days 7 to 9 , followed by a decrease until day 14 (Figure 3B). Again, 5000 cells / well was the initial cell density chosen to proceed, considering the higher diameter and metabolic activity. At selected time-points, days 7 and 14, the parameters of viability, ROS, and apoptosis revealed permeabilization of cells (labeled in red). ROS production was higher on day 7 than on day 14, and apoptosis was negligible (Figure 3C). Based on these results, we considered an initial cell density of 5000 cells/well and a growth period of 7 days as the best regimen conditions (Video S3). 
A

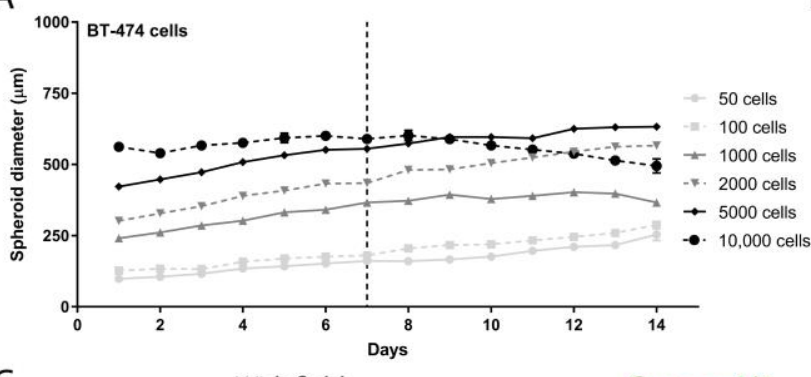

C

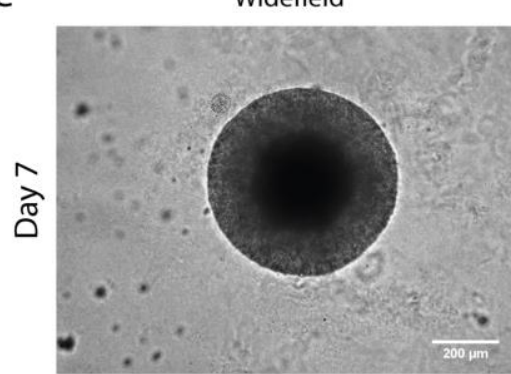

Caspase-3/7

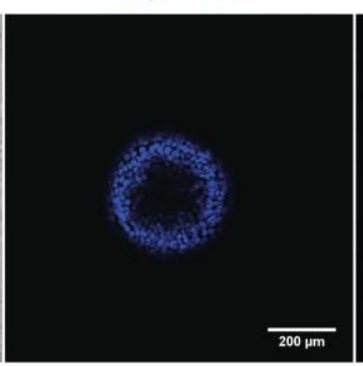

B
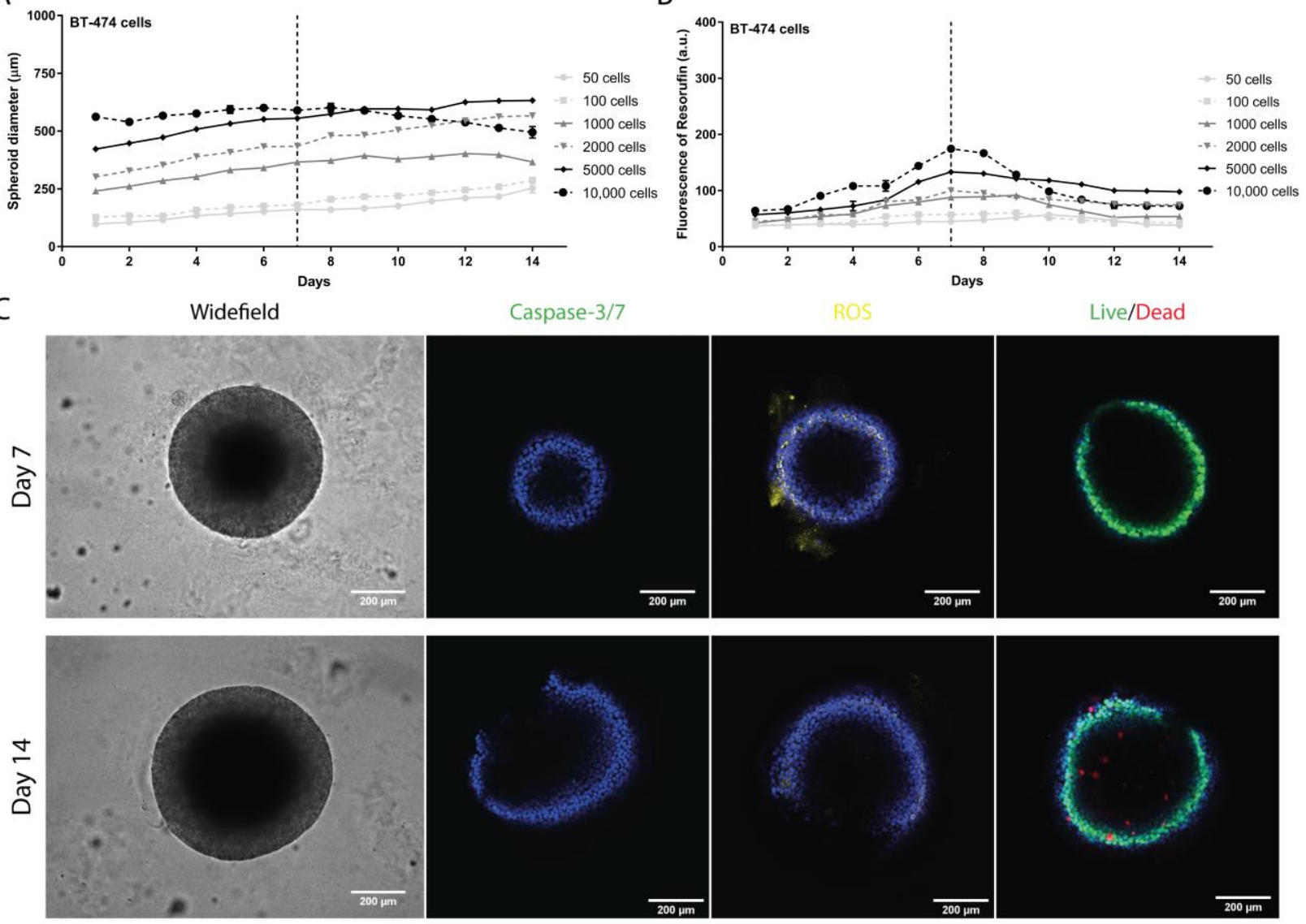

Figure 3. Evaluation of the BT-474 spheroid formation. (A) Spheroid diameter $(\mu \mathrm{m})$ daily monitoring over 14 days measured with a widefield fluorescence microscope. (B) Spheroid cell metabolic activity daily evaluation over 14 days by measuring the fluorescence emission of resorufin with a microplate reader. (C) Representative images of parameters evaluated on days 7 and 14 at 5000 cells/well with a confocal point-scanning Zeiss LSM 880 microscope. In the apoptosis determination, apoptotic cells are marked in green; in the oxidative stress measurement, reactive oxygen species (ROS) are marked in yellow; and in the cell viability/mortality evaluation, intact cells (live) are marked in green and permeabilized cells (dead) in red. In all experiments, cell nucleus is marked in blue. Scale bar $=200 \mu \mathrm{m}$. Graphs represent at least three biological repeats.

\subsection{Ultrastructure of Spheroids}

The organization and ultrastructure of spheroids were analyzed by TEM in MDA-MB231 (Figure 4A-D), BT-20 (Figure 4E-H), and BT-474 (Figure 4I-L) under the previously optimized conditions. Low magnification TEM showed cell-cell proximity with sporadic villosities in tissue-like fashion, revealing intact adjoined cells within the spheroid. At higher magnifications, the presence of normal and abnormal phenotype-associated mitochondria was observed, as well as rough and smooth endoplasmic reticulum without abnormal features, and lysosomes. Other organelles, as well as the nuclear membrane, showed typical morphology for the phenotype. 
MDA-MB-231 cells
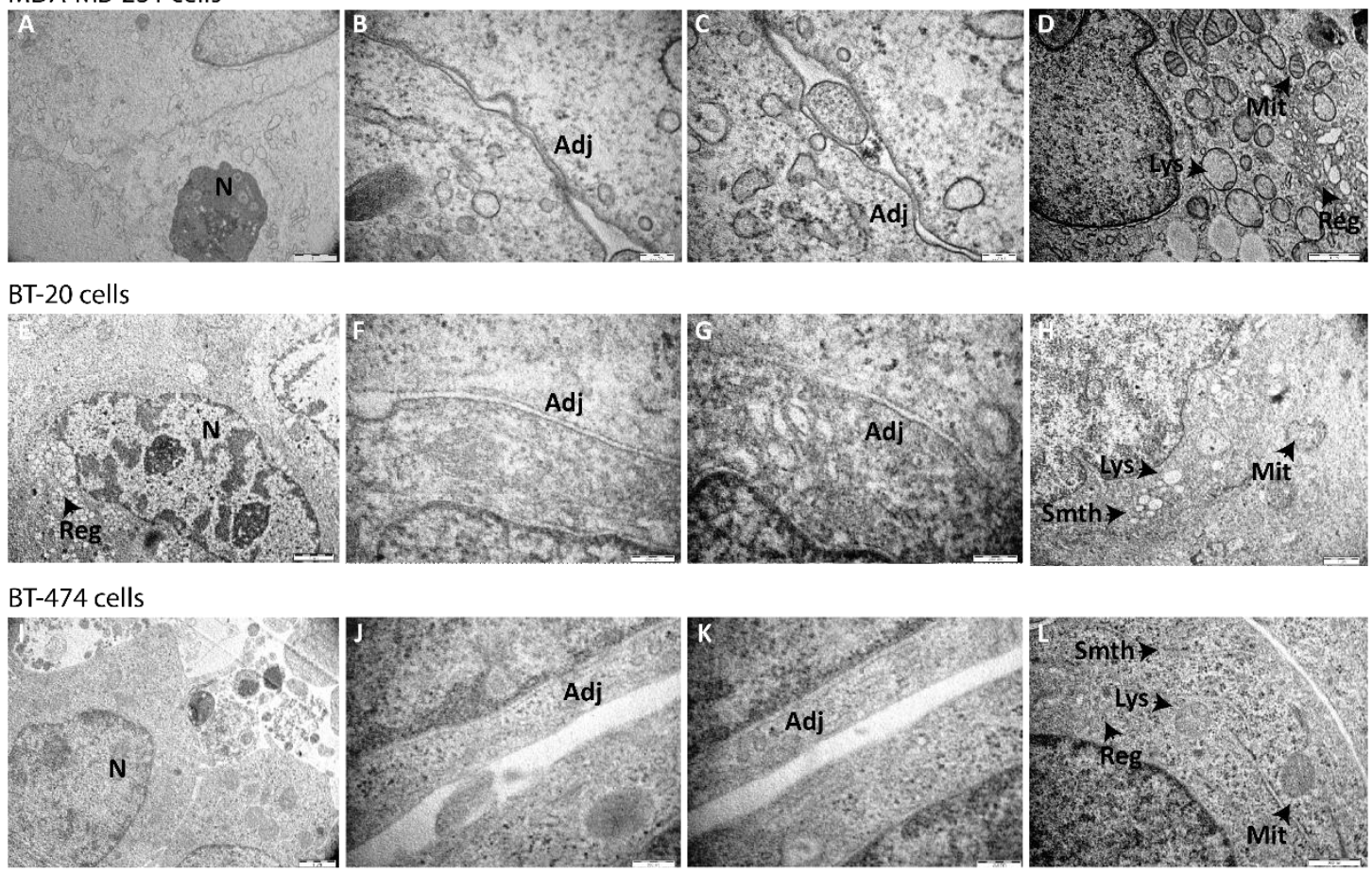

Figure 4. Ultrastructure of MDA-MB-231, BT-20, and BT-474 spheroids by transmission electron microscopy (TEM). Images of (A-D) MDA-MB-231, (E-H) BT-20, and (I-L) BT-474 spheroids formed under optimized conditions were acquired after 7 days of culture with TEM microscope Hitachi H-7000. Scale bars are shown on all images. $\mathrm{N}=$ nucleus; Adj= adjoined connections; $\mathrm{Mit}=$ mitochondria; Lys = lysosome; Reg = rough endoplasmic reticulum; Smth = smooth endoplasmic reticulum.

\subsection{Peptide Anticancer Activity in Cell Monolayers and Spheroids}

The activity of vCPP2319 was evaluated in monolayers of MDA-MB-231, BT-20, and BT- 474 cells for $24 \mathrm{~h}$, with the $\mathrm{IC}_{50}$ values reported in Table 2 . In this case, vCPP2319 demonstrated a high elimination efficiency towards TNBC cell lines, with $\mathrm{IC}_{50}$ values around $4.5 \mu \mathrm{M}$. The elimination capacity towards BT- 474 cells was less marked, with an $\mathrm{IC}_{50}$ three times higher. As a control, cytotoxicity was evaluated against $\mathrm{PepH}$, a wellknown blood-brain barrier peptide shuttle (BBBpS) [48,49]. As expected, PepH3 showed no activity up to $100.0 \mu \mathrm{M}$, despite its ability to penetrate cell barriers.

Table 2. Anticancer activity of peptides in cell monolayers and spheroids.

\begin{tabular}{ccccccc}
\hline & \multicolumn{4}{c}{ IC $_{50}$ Values $[\mu \mathrm{M}]$} \\
\cline { 2 - 6 } Peptide & \multicolumn{4}{c}{ TNBC Cells } & \multicolumn{2}{c}{ HER2+ Cells } \\
\cline { 2 - 6 } & \multicolumn{2}{c}{ MDA-MB-231 } & \multicolumn{2}{c}{ BT-20 } & \multicolumn{2}{c}{ BT-474 } \\
\cline { 2 - 6 } & Monolayer * $^{*}$ Spheroid $^{\#}$ & Monolayer $^{*}$ & Spheroid $^{\#}$ & Monolayer * $^{*}$ Spheroid $^{\#}$ \\
\hline PepH3 & $>100$ & $>100$ & $>100$ & $>100$ & $>100$ & $>100$ \\
vCPP2319 & $4.5 \pm 0.07$ & $22.1 \pm 3.67$ & $4.2 \pm 2.22$ & $21.3 \pm 2.98$ & $15.7 \pm 1.46$ & $47.9 \pm 3.97$ \\
\hline
\end{tabular}

$\mathrm{IC}_{50}$ is the concentration causing $50 \%$ death of cells. HER2, Human epidermal growth factor receptor-2; TNBC, Triple-negative breast cancer; ${ }^{*}$, results upon 24-h incubation; ${ }^{*}$, results upon 5-day incubation.

The efficacy of vCPP2319 was also evaluated on spheroids using the previously optimized regimens. After development, spheroids were exposed to increasing peptide concentrations $(0.05-100.0 \mu \mathrm{M})$ up to 5 days (Figure S1 and Table S1). A stable $\mathrm{IC}_{50}$ value was observed upon 5 day incubation (best anticancer activity reported), with results shown in Table 2. Overall, the $\mathrm{IC}_{50}$ values of vCPP2319 towards spheroids were higher than for cell monolayers. Again, as in cell monolayers, PepH3 did not show anticancer activity. 


\subsection{Effect of Peptide Treatment on Spheroids}

The effect of vCPP2319 on apoptosis, ROS production, and cell permeabilization of spheroids was assessed over 5-day incubation at $\mathrm{IC}_{50}$ value, followed by quantitative analysis by confocal microscopy (Figure 5). For all spheroids, vCPP2319 treatment caused alterations in cell apoptosis, ROS production, and cell viability. Thus, the peptide significantly decreased apoptotic cells compared to control ( $p<0.0001$ for all cell lines). Then, it significantly increased the fluorescence emission resulting from ROS production compared to the control ( $p<0.0001$ for all cell lines). Finally, vCPP2319 was capable of efficiently permeabilizing cancer cells (dead), as revealed by live/dead assay compared to control ( $p<0.0001$ for all cell lines). PepH3, also used as a control in each assay, did not produce statistically significant alteration in the spheroid microenvironment, despite its ability to penetrate cell barriers.
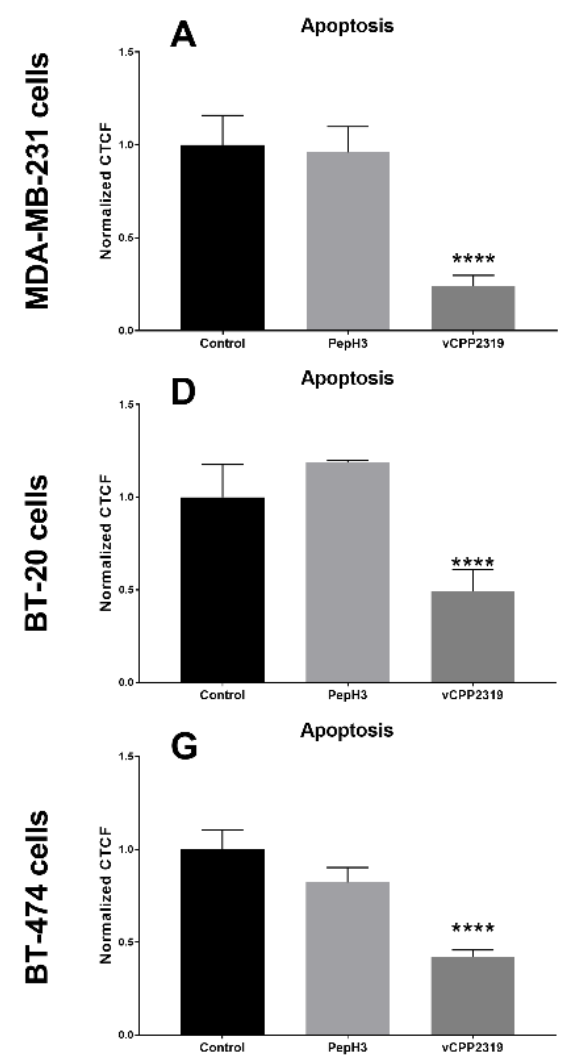

B

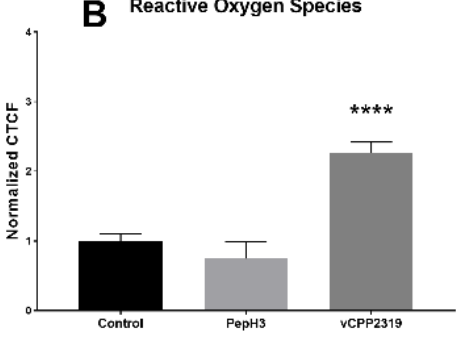

E

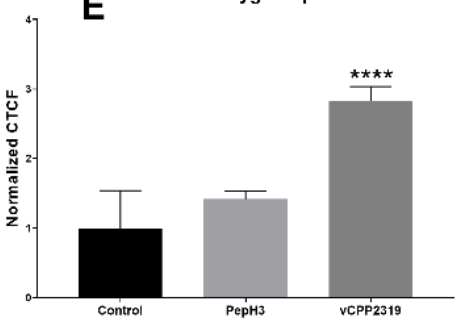

H

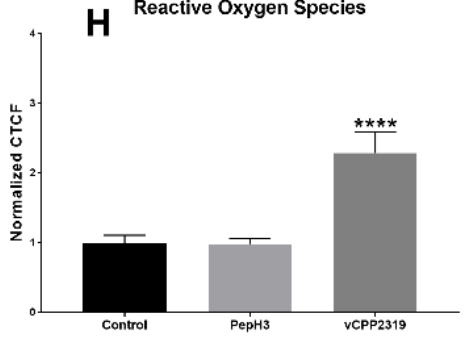

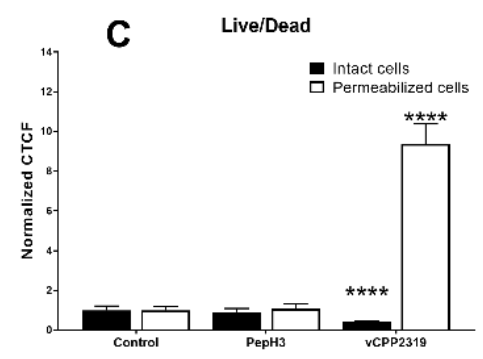

$\mathbf{F}$

Live/Dead

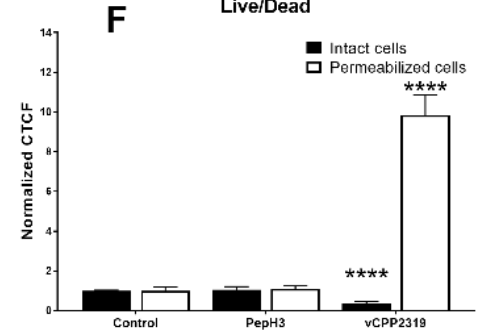

Live/Dead

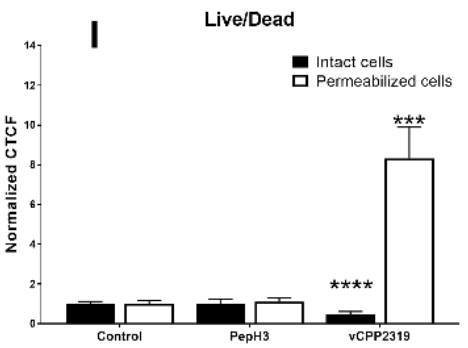

Figure 5. Confocal microscopy characterization of apoptosis, reactive oxygen species (ROS) production, and cell viability /mortality in spheroids after treatment with peptides. Apoptosis, ROS production, and cell viability/mortality of (A-C) MDA-MB-231, (D-F) BT-20, and (G-I) BT-474 spheroids, formed under optimized conditions, after treatment for 5 days with vCPP2319 and PepH3 were assessed using a confocal point-scanning Zeiss LSM 880 microscope. The analysis was performed by calculating the corrected total cell fluorescence (CTCF) of different images and CTCF normalized to control. Graphs represent at least triplicate biological repeats, and results are displayed as mean $\pm \mathrm{SD}$, where ${ }^{*} p<0.05,{ }^{* *} p<0.01$, $* * * p<0.001$, and ${ }^{* * * *} p<0.0001$.

\section{Discussion}

The use of 3D cell cultures has attracted increasing interest as being more representative of in vivo conditions than 2D cultures [50]. For cancer research, it is particularly important to consider the unique properties of the tumor microenvironment, which can affect therapeutic efficacy [51,52]. Spheroids can better reproduce tumor hypoxia, expression of extracellular matrix proteins, intracellular interactions, and growth factor exchanges [15-17]. In the literature, numerous examples of tumor cell line-derived 
spheroids can be found using different cancer cell lines, but only some include their evaluation against an anticancer drug $[25,28,31-41,53]$, which is usually a chemotherapeutic agent and not an anticancer peptide, as evaluated in this work. Additionally, a full characterization of the effect of therapeutics on apoptosis and ROS production is sometimes missing.

To develop spheroids representing hard-to-treat BC subtypes, namely TNBC and HER2+, we optimized preparation conditions using three cell lines (MDA-MB-231, BT-20, and BT-474 cells) selected for their importance in in vitro cancer research. The liquid overlay technique, which relies mainly on gravity, was used to generate these spheroids [54]. As extracellular matrix is needed to develop compact and homogeneous spheroids [30,55], 2\% $(v / v)$ GelTrex ${ }^{\circledR}$ LDEV-Free was used [28]. Our results showed that spheroids produced with either 2000 cells/well (MDA-MB-231) or 5000 cells/well (BT-20 and BT-474) reached a stable diameter (below $1 \mathrm{~mm}$ ) and higher metabolic activity at 7 days (Figure 1). MDAMB-231 cells displayed a faster expansion than BT-20 and BT-474, in tune with their high proliferative nature [56], thus requiring fewer initial cells. Eventually, the 3D structure reached a senescent state due to lack of nutrients or hypoxia, as shown by the absence of cell death increase in the live/dead assay $[57,58]$. This was confirmed by evaluation of apoptosis, ROS production, and cell permeabilization (live/dead) (Figures 1-3 and Videos S1 and S2). These results are consistent with previous reports $[28,39,40]$.

Cellular organization and ultrastructure of spheroids at day 7 were analyzed by TEM. The results showed the presence of intact cells adjoined in a tissue-like fashion. Inside cells, organelles such as mitochondria, rough and smooth endoplasmic reticulum, and lysosomes showed the typical phenotype morphology (Figure 4).

To assess the cytotoxic activity of vCPP2319, an ACP discovered by our group [43,44], spheroids presenting higher diameter and metabolic activity (day 7) were used. For comparison, vCPP2319 cytotoxicity towards cell monolayers was also tested. Results showed higher antitumor potency in TNBC than in HER2+ cells, with a 2-fold higher $\mathrm{IC}_{50}$ value for HER2+ spheroids. IC 50 value also differed between monolayers and spheroids, in both $\mathrm{TNBC}\left(\mathrm{IC}_{50}\right.$ (monolayer) $\approx 4.5 \mu \mathrm{M}$ after $24 \mathrm{~h}$, vs. $\mathrm{IC}_{50}$ (spheroid) $\approx 20.0 \mu \mathrm{M}$ after 5 days) and HER $2+\left(\mathrm{IC}_{50}\right.$ (monolayer) $\approx 15.7 \mu \mathrm{M}$ after $24 \mathrm{~h}$, vs. IC $\mathrm{I}_{50}$ (spheroid) $\approx 47.9 \mu \mathrm{M}$ after 5 days) (Table 2). Anticancer activity of vCPP2319 in spheroids was monitored over 5 days and a time-dependent action was observed, with $\mathrm{IC}_{50}$ values ranging between $62.0-87.0 \mu \mathrm{M}$ at $24 \mathrm{~h}$ and $21.0-47.0 \mu \mathrm{M}$ at day 5 (Table S1 and Figure S1). To validate the cytotoxic effect of vCPP2319, PepH3, a BBBpS, was used as negative control due to the lack of anticancer activity $[43,48,49]$. Results revealed no cytotoxic effect of PepH3 (Table 2 and Figure S1). The differences observed between both models might be related to increased complexity in the spheroid, including cellular heterogeneity and/or resistance phenotypes. Moreover, the ultrastructure, which includes extracellular matrix, likely decreases the peptide's ability to penetrate cells, reducing its efficacy, similarly to what is observed in tumor response in vivo [59].

The cytotoxic effect of vCPP2319 was further demonstrated through evaluation of apoptotic cells, ROS production, and cell permeabilization in control spheroids and spheroids treated with vCPP2319 and PepH3 (Figure 5). Our results revealed increased ROS production and cell permeabilization. Fewer apoptotic cells were visualized in spheroids treated with vCPP2319, when compared with controls, which means that cells were already compromised or were already dead at the time of detection (Figure 5). A decrease in potency has been reported already in other studies [60-62]. Based on these findings, we suggest that anticancer drug candidates should be tested in spheroids to properly characterize their efficacy. In addition to those in the present work, other cancer cell lines can be used to better mimic other subtypes.

Taken together, our results have demonstrated the relevance of 3D cell culture models for better representing in vivo tumors. Nevertheless, our study has some differences compared to other studies, such as the lack of co-culture with stromal cells (such as fibroblasts), and the comparison of the efficacy of an anticancer peptide towards spheroids 
and cell monolayers instead of a well-established chemotherapeutic agent. However, using our optimized spheroids, we showed that the sensitivity of 2D and 3D models to different drugs, such as the ACP, was different; thus, the use of 2D models might not be accurate when considering what happens in the in vivo setting. This highlights the advantage of BC spheroid models as drug screening platforms to afford better chances of success. Considering the recent efforts to develop anticancer peptides, which present advantages over traditional chemotherapy, it is important to show the need for complex models to properly assess peptide activity.

\section{Conclusions}

Three-dimensional cell culture models are increasingly viewed as essential for the preclinical evaluation of drug candidates (particularly anticancer) as they are closer to the in vivo setting than 2D cultures. During R\&D on new therapeutic molecules, testing their efficacy in 3D models avoids overestimation of cytotoxic efficacy. In this study, we successfully determined the best regimen for developing TNBC spheroids from MDA-MB31 and BT-20 cell lines, and HER2+ spheroids from BT-474. The characterization of each spheroid revealed different tumor microenvironment properties. We also compared cell monolayers and spheroids in their response to an ACP. The spheroids were less sensitive than the monolayers to the peptide tested, which illustrates the need for preclinical models that properly mimic the in vivo setting. The spheroids in this study are valuable tools for preclinical assessment of newly developed anticancer drugs.

Supplementary Materials: The following are available online at https: / www.mdpi.com/article / 10.3390/pharmaceutics13111863/s1, Table S1: Anticancer activity of peptides on 3D cell cultures over 5 days, Figure S1: In vitro cytotoxicity of peptides towards different cancer cell lines with an incubation up to 5 days, Video S1: Development of MDA-MB-231 cell line spheroids, Video S2: Development of BT-20 cell line spheroids, Video S3: Development of BT-474 cell line spheroids.

Author Contributions: Conceptualization, M.C., P.F., D.A., M.A.R.B.C. and V.N.; Data curation, M.C., P.F., D.A., M.A.R.B.C. and V.N.; Formal analysis, M.C., P.F., D.A., M.A.R.B.C. and V.N.; Funding acquisition, D.A., M.A.R.B.C. and V.N.; Investigation, M.C., P.F. and J.V.; Methodology, M.C., P.F., D.A., M.A.R.B.C. and V.N.; Project administration, D.A., M.A.R.B.C. and V.N.; Resources, D.A., M.A.R.B.C. and V.N.; Supervision, M.C., D.A., M.A.R.B.C. and V.N.; Validation, D.A., M.A.R.B.C. and V.N.; Visualization, D.A., M.A.R.B.C. and V.N.; Writing-original draft, M.C., P.F., D.A., M.A.R.B.C. and V.N.; Writing-review and editing, M.C., P.F., D.A., M.A.R.B.C. and V.N. All authors have read and agreed to the published version of the manuscript.

Funding: This research was funded by Portuguese Funding Agency, Fundação para a Ciência e a Tecnologia, FCT IP (grants: PD/BD/128281/2017, PTDC/BIA-BQM/5027/2020, and DL 57/2016/ CP1451/CT0023); and "la Caixa" Banking Foundation (grant HR17-00409), under the agreement $\mathrm{LCF} / \mathrm{PR} / \mathrm{HR} 17 / 5215001$.

Institutional Review Board Statement: Not applicable.

Informed Consent Statement: Not applicable.

Data Availability Statement: Not applicable.

Acknowledgments: Our thanks to Pedro Pereira for his technical work with TEM technology and to Ana Herdade for her insights on the work development.

Conflicts of Interest: The authors declare no conflict of interest.

\section{References}

1. Torre, L.A.; Islami, F.; Siegel, R.L.; Ward, E.M.; Jemal, A. Global Cancer in Women: Burden and Trends. Cancer Epidemiol. Biomark. Prev. 2017, 26, 444. [CrossRef] [PubMed]

2. O'Sullivan, C.C.; Loprinzi, C.L.; Haddad, T.C. Updates in the Evaluation and Management of Breast Cancer. Mayo Clin. Proc. 2018, 93, 794-807. [CrossRef] [PubMed]

3. Corben, A.D. Pathology of Invasive Breast Disease. Surg. Clin. N. Am. 2013, 93, 363-392. [CrossRef] [PubMed]

4. Waks, A.G.; Winer, E.P. Breast Cancer Treatment: A Review. JAMA 2019, 321, 288-300. [CrossRef] 
5. Joshi, H.; Press, M.F. 22-Molecular Oncology of Breast Cancer. In The Breast, 5th ed.; Bland, K.I., Copeland, E.M., Klimberg, V.S., Gradishar, W.J., Eds.; Elsevier: Amsterdam, The Netherlands, 2018; pp. 282-307.e5.

6. Hammond, M.E.H.; Hayes, D.F.; Dowsett, M.; Allred, D.C.; Hagerty, K.L.; Badve, S.; Fitzgibbons, P.L.; Francis, G.; Goldstein, N.S.; Hayes, M.; et al. American Society of Clinical Oncology/College of American Pathologists Guideline Recommendations for Immunohistochemical Testing of Estrogen and Progesterone Receptors in Breast Cancer. J. Clin. Oncol. 2010, 28, $2784-2795$. [CrossRef]

7. Piccart-Gebhart, M.J.; Procter, M.; Leyland-Jones, B.; Goldhirsch, A.; Untch, M.; Smith, I.; Gianni, L.; Baselga, J.; Bell, R.; Jackisch, C.; et al. Trastuzumab after Adjuvant Chemotherapy in HER2-Positive Breast Cancer. N. Engl. J. Med. 2005, 353, 1659-1672. [CrossRef]

8. Wolff, A.C.; Hammond, M.E.H.; Hicks, D.G.; Dowsett, M.; McShane, L.M.; Allison, K.H.; Allred, D.C.; Bartlett, J.M.S.; Bilous, M.; Fitzgibbons, P.; et al. Recommendations for Human Epidermal Growth Factor Receptor 2 Testing in Breast Cancer: American Society of Clinical Oncology/College of American Pathologists Clinical Practice Guideline Update. J. Clin. Oncol. 2013, 31, 3997-4013. [CrossRef]

9. Denkert, C.; Liedtke, C.; Tutt, A.; von Minckwitz, G. Molecular alterations in triple-negative breast cancer-The road to new treatment strategies. Lancet 2017, 389, 2430-2442. [CrossRef]

10. Foulkes, W.D.; Smith, I.E.; Reis-Filho, J.S. Triple-Negative Breast Cancer. N. Engl. J. Med. 2010, 363, 1938-1948. [CrossRef]

11. Seyhan, A.A. Lost in translation: The valley of death across preclinical and clinical divide-Identification of problems and overcoming obstacles. Transl. Med. Commun. 2019, 4, 18. [CrossRef]

12. Cherny, N.I.; Paluch-Shimon, S.; Berner-Wygoda, Y. Palliative care: Needs of advanced breast cancer patients. Breast Cancer Dove Med. Press 2018, 10, 231-243. [CrossRef] [PubMed]

13. Chen, J.; Luo, X.; Qiu, H.; Mackey, V.; Sun, L.; Ouyang, X. Drug discovery and drug marketing with the critical roles of modern administration. Am. J. Transl. Res. 2018, 10, 4302-4312.

14. Edmondson, R.; Broglie, J.J.; Adcock, A.F.; Yang, L. Three-dimensional cell culture systems and their applications in drug discovery and cell-based biosensors. Assay Drug Dev. Technol. 2014, 12, 207-218. [CrossRef]

15. Weaver, V.M.; Petersen, O.W.; Wang, F.; Larabell, C.A.; Briand, P.; Damsky, C.; Bissell, M.J. Reversion of the malignant phenotype of human breast cells in three-dimensional culture and in vivo by integrin blocking antibodies. J. Cell Biol. 1997, 137, 231-245. [CrossRef] [PubMed]

16. Birgersdotter, A.; Sandberg, R.; Ernberg, I. Gene expression perturbation in vitro-A growing case for three-dimensional (3D) culture systems. Semin. Cancer Biol. 2005, 15, 405-412. [CrossRef]

17. Bhadriraju, K.; Chen, C.S. Engineering cellular microenvironments to improve cell-based drug testing. Drug Discov. Today 2002, 7 , 612-620. [CrossRef]

18. Poltavets, V.; Kochetkova, M.; Pitson, S.M.; Samuel, M.S. The Role of the Extracellular Matrix and Its Molecular and Cellular Regulators in Cancer Cell Plasticity. Front. Oncol. 2018, 8, 431. [CrossRef]

19. Kola, I. The State of Innovation in Drug Development. Clin. Pharmacol. Ther. 2008, 83, 227-230. [CrossRef]

20. Breslin, S.; O'Driscoll, L. Three-dimensional cell culture: The missing link in drug discovery. Drug Discov. Today 2013, 18, 240-249. [CrossRef]

21. Hopkins, A.L. Network pharmacology: The next paradigm in drug discovery. Nat. Chem. Biol. 2008, 4, 682-690. [CrossRef]

22. Proctor, W.R.; Foster, A.J.; Vogt, J.; Summers, C.; Middleton, B.; Pilling, M.A.; Shienson, D.; Kijanska, M.; Ströbel, S.; Kelm, J.M.; et al. Utility of spherical human liver microtissues for prediction of clinical drug-induced liver injury. Arch. Toxicol. 2017, 91, 2849-2863. [CrossRef] [PubMed]

23. Sachs, N.; de Ligt, J.; Kopper, O.; Gogola, E.; Bounova, G.; Weeber, F.; Balgobind, A.V.; Wind, K.; Gracanin, A.; Begthel, H.; et al. A Living Biobank of Breast Cancer Organoids Captures Disease Heterogeneity. Cell 2018, 172, 373-386.e10. [CrossRef]

24. Boo, L.; Ho, W.Y.; Mohd Ali, N.; Yeap, S.K.; Ky, H.; Chan, K.G.; Yin, W.F.; Satharasinghe, D.A.; Liew, W.C.; Tan, S.W.; et al. Phenotypic and microRNA transcriptomic profiling of the MDA-MB-231 spheroid-enriched CSCs with comparison of MCF-7 microRNA profiling dataset. PeerJ 2017, 5, e3551. [CrossRef] [PubMed]

25. Goertzen, C.; Eymael, D.; Magalhaes, M. Three-Dimensional Quantification of Spheroid Degradation-Dependent Invasion and Invadopodia Formation. Biol. Proced. Online 2018, 20, 20. [CrossRef] [PubMed]

26. Nii, T.; Makino, K.; Tabata, Y. Three-Dimensional Culture System of Cancer Cells Combined with Biomaterials for Drug Screening. Cancers 2020, 12, 2754. [CrossRef]

27. Chaicharoenaudomrung, N.; Kunhorm, P.; Noisa, P. Three-dimensional cell culture systems as an in vitro platform for cancer and stem cell modeling. World J. Stem Cells 2019, 11, 1065-1083. [CrossRef]

28. Dubois, C.; Dufour, R.; Daumar, P.; Aubel, C.; Szczepaniak, C.; Blavignac, C.; Mounetou, E.; Penault-Llorca, F.; Bamdad, M. Development and cytotoxic response of two proliferative MDA-MB-231 and non-proliferative SUM1315 three-dimensional cell culture models of triple-negative basal-like breast cancer cell lines. Oncotarget 2017, 8, 95316-95331. [CrossRef]

29. Dubois, C.; Daumar, P.; Aubel, C.; Gauthier, J.; Vidalinc, B.; Mounetou, E.; Penault-Llorca, F.; Bamdad, M. The New Synthetic Serum-Free Medium OptiPASS Promotes High Proliferation and Drug Efficacy Prediction on Spheroids from MDA-MB-231 and SUM1315 Triple-Negative Breast Cancer Cell Lines. J. Clin. Med. 2019, 8, 397. [CrossRef]

30. Shin, C.S.; Kwak, B.; Han, B.; Park, K. Development of an in vitro 3D tumor model to study therapeutic efficiency of an anticancer drug. Mol. Pharm. 2013, 10, 2167-2175. [CrossRef] 
31. Wong, C.-W.; Han, H.-W.; Tien, Y.-W.; Hsu, S.-h. Biomaterial substrate-derived compact cellular spheroids mimicking the behavior of pancreatic cancer and microenvironment. Biomaterials 2019, 213, 119202. [CrossRef] [PubMed]

32. Nii, T.; Kuwahara, T.; Makino, K.; Tabata, Y. A Co-Culture System of Three-Dimensional Tumor-Associated Macrophages and Three-Dimensional Cancer-Associated Fibroblasts Combined with Biomolecule Release for Cancer Cell Migration. Tissue Eng. Part A 2020, 26, 1272-1282. [CrossRef]

33. Gunay, G.; Kirit, H.A.; Kamatar, A.; Baghdasaryan, O.; Hamsici, S.; Acar, H. The effects of size and shape of the ovarian cancer spheroids on the drug resistance and migration. Gynecol. Oncol. 2020, 159, 563-572. [CrossRef] [PubMed]

34. Sapudom, J.; Kalbitzer, L.; Wu, X.; Martin, S.; Kroy, K.; Pompe, T. Fibril bending stiffness of 3D collagen matrices instructs spreading and clustering of invasive and non-invasive breast cancer cells. Biomaterials 2019, 193, 47-57. [CrossRef] [PubMed]

35. Han, H.-W.; Hsu, S.-h. Chitosan-hyaluronan based 3D co-culture platform for studying the crosstalk of lung cancer cells and mesenchymal stem cells. Acta Biomater. 2016, 42, 157-167. [CrossRef]

36. Nii, T.; Makino, K.; Tabata, Y. A Cancer Invasion Model Combined with Cancer-Associated Fibroblasts Aggregates Incorporating Gelatin Hydrogel Microspheres Containing a p53 Inhibitor. Tissue Eng. Part C Methods 2019, 25, 711-720. [CrossRef] [PubMed]

37. Pan, Y.; Jiang, D.; Gu, C.; Qiu, Y.; Wan, H.; Wang, P. 3D microgroove electrical impedance sensing to examine 3D cell cultures for antineoplastic drug assessment. Microsyst. Nanoeng. 2020, 6, 23. [CrossRef]

38. Folkesson, E.; Niederdorfer, B.; Nakstad, V.T.; Thommesen, L.; Klinkenberg, G.; Lægreid, A.; Flobak, Å. High-throughput screening reveals higher synergistic effect of MEK inhibitor combinations in colon cancer spheroids. Sci. Rep. 2020, 10, 11574. [CrossRef]

39. Gencoglu, M.; Barney, L.; Hall, C. Comparative Study of Multicellular Tumor Spheroid Formation Methods and Implications for Drug Screening. ACS Biomater. Sci. Eng. 2018, 4, 410-420. [CrossRef]

40. Saraiva, D.P.; Matias, A.T.; Braga, S.; Jacinto, A.; Cabral, M.G. Establishment of a 3D Co-culture with MDA-MB-231 Breast Cancer Cell Line and Patient-Derived Immune Cells for Application in the Development of Immunotherapies. Front. Oncol. 2020, 10, 1543. [CrossRef]

41. Yakavets, I.; Francois, A.; Benoit, A.; Merlin, J.-L.; Bezdetnaya, L.; Vogin, G. Advanced co-culture 3D breast cancer model for investigation of fibrosis induced by external stimuli: Optimization study. Sci. Rep. 2020, 10, 21273. [CrossRef]

42. Holliday, D.L.; Speirs, V. Choosing the right cell line for breast cancer research. Breast Cancer Res. 2011, 13, 215. [CrossRef] [PubMed]

43. Cavaco, M.; Pérez-Peinado, C.; Valle, J.; Silva, R.D.M.; Correia, J.D.G.; Andreu, D.; Castanho, M.A.R.B.; Neves, V. To What Extent Do Fluorophores Bias the Biological Activity of Peptides? A Practical Approach Using Membrane-Active Peptides as Models. Front. Bioeng. Biotechnol. 2020, 8, 1059. [CrossRef] [PubMed]

44. Oliveira, F.; Cavaco, M.; Figueira, T.; Valle, J.; Neves, V.; Andreu, D.; Gaspar, D.; Castanho, M. The antimetastatic breast cancer activity of the viral protein-derived peptide vCPP2319 as revealed by cellular biomechanics. FEBS J. 2021, 16247. [CrossRef]

45. Cavaco, M.; Castanho, M.A.R.B.; Neves, V. Peptibodies: An elegant solution for a long-standing problem. Pept. Sci. 2018, 110, e23095. [CrossRef]

46. Marqus, S.; Pirogova, E.; Piva, T.J. Evaluation of the use of therapeutic peptides for cancer treatment. J. Biomed. Sci. 2017, 24, 21. [CrossRef]

47. Bidwell, G.L. Peptides for cancer therapy: A drug-development opportunity and a drug-delivery challenge. Ther. Deliv. 2012, 3, 609-621. [CrossRef] [PubMed]

48. Cavaco, M.; Valle, J.; Silva, R.D.M.; Correia, J.D.G.; Castanho, M.A.R.B.; Andreu, D.; Neves, V. ${ }_{D}$ PepH3, an Improved Peptide Shuttle for Receptor-independent Transport Across the Blood-Brain Barrier. Curr. Pharm. Des. 2020, 26, 1495-1506. [CrossRef] [PubMed]

49. Neves, V.; Aires-da-Silva, F.; Morais, M.; Gano, L.; Ribeiro, E.; Pinto, A.; Aguiar, S.; Gaspar, D.; Fernandes, C.; Correia, J.D.G.; et al. Novel peptides derived from Dengue virus capsid protein translocate reversibly the blood-brain barrier through a receptor-free mechanism. ACS Chem. Biol. 2017, 12, 1257-1268. [CrossRef]

50. Langhans, S.A. Three-Dimensional in Vitro Cell Culture Models in Drug Discovery and Drug Repositioning. Front. Pharmacol. 2018, 9, 6. [CrossRef]

51. Sanegre, S.; Lucantoni, F.; Burgos-Panadero, R.; de La Cruz-Merino, L.; Noguera, R.; Álvaro Naranjo, T. Integrating the Tumor Microenvironment into Cancer Therapy. Cancers 2020, 12, 1677. [CrossRef]

52. Baghban, R.; Roshangar, L.; Jahanban-Esfahlan, R.; Seidi, K.; Ebrahimi-Kalan, A.; Jaymand, M.; Kolahian, S.; Javaheri, T.; Zare, P. Tumor microenvironment complexity and therapeutic implications at a glance. Cell Commun. Signal. 2020, 18, 59. [CrossRef] [PubMed]

53. Hirschhaeuser, F.; Menne, H.; Dittfeld, C.; West, J.; Mueller-Klieser, W.; Kunz-Schughart, L.A. Multicellular tumor spheroids: An underestimated tool is catching up again. J. Biotechnol. 2010, 148, 3-15. [CrossRef]

54. Costa, E.C.; Gaspar, V.M.; Coutinho, P.; Correia, I.J. Optimization of liquid overlay technique to formulate heterogenic 3D co-cultures models. Biotechnol. Bioeng. 2014, 111, 1672-1685. [CrossRef] [PubMed]

55. Kleinman, H.K.; Martin, G.R. Matrigel: Basement membrane matrix with biological activity. Semin. Cancer Biol. 2005, 15, 378-386. [CrossRef] 
56. Li, Q.; Chen, C.; Kapadia, A.; Zhou, Q.; Harper, M.K.; Schaack, J.; Labarbera, D.V. 3D Models of Epithelial-Mesenchymal Transition in Breast Cancer Metastasis: High-Throughput Screening Assay Development, Validation, and Pilot Screen. J. Biomol. Screen. 2011, 16, 141-154. [CrossRef]

57. Charoen, K.M.; Fallica, B.; Colson, Y.L.; Zaman, M.H.; Grinstaff, M.W. Embedded multicellular spheroids as a biomimetic 3D cancer model for evaluating drug and drug-device combinations. Biomaterials 2014, 35, 2264-2271. [CrossRef] [PubMed]

58. Wang, B.; Kohli, J.; Demaria, M. Senescent Cells in Cancer Therapy: Friends or Foes? Trends Cancer 2020, 6, 838-857. [CrossRef] [PubMed]

59. Costa, E.C.; Moreira, A.F.; Duarte de Melo, D.; Gaspar, V.M.; Carvalho, M.P.; Correia, I.J. 3D tumor spheroids: An overview on the tools and techniques used for their analysis. Biotechnol. Adv. 2016, 34, 1427-1441. [CrossRef]

60. Casagrande, N.; Borghese, C.; Gabbatore, L.; Morbiato, L.; De Zotti, M.; Aldinucci, D. Analogs of a Natural Peptaibol Exert Anticancer Activity in Both Cisplatin- and Doxorubicin-Resistant Cells and in Multicellular Tumor Spheroids. Int. J. Mol. Sci. 2021, 22, 8362. [CrossRef]

61. Han, S.J.; Kwon, S.; Kim, K.S. Challenges of applying multicellular tumor spheroids in preclinical phase. Cancer Cell Int. 2021, 21, 152. [CrossRef]

62. Kiyomi, A.; Miyakawa, R.; Matsumoto, J.; Yamazaki, K.; Imai, S.; Yuan, B.; Hirano, T.; Sugiura, M. Potent antitumor activity of cepharanthine against triple-negative breast cancer spheroids compared with tetrandrine. Oncol. Lett. 2020, 20, 331. [CrossRef] [PubMed] 